\title{
Stabilisation of landslides using gravity fed siphon and electro-pneumatic pumped wells: two examples of slope stabilisation projects from the United Kingdom and Czech Republic
}

\author{
J.K. Holliday Aurecon Australia Pty Ltd, Australia (formerly High Point Rendel, UK)
}

A.R. Clark Independent consultant, UK (formerly High Point Rendel, UK)

D.S. Fort Atkins, UK (formerly High Point Rendel, UK)

A. Gillarduzzi High Point Rendel, UK

S. Bomont TPGEO, France

\begin{abstract}
The rise of groundwater in response to extreme weather events is having a major impact on slope stability and the consequential disruption to infrastructure services and associated costs related to their repair is significant.
\end{abstract}

Climate change studies are predicting increased frequency and duration of extreme weather events. Case histories have demonstrated the link between prolonged rainfall events, rising groundwater levels and increased frequency of slope instability.

The stability of slopes can be improved if groundwater can be controlled and this is most commonly achieved through the use of drainage measures. An innovative drainage system that uses siphon drain and electro-pneumatic pump technology has been employed in Europe since 1986 using drains and lines of wells to lower and maintain groundwater levels within slopes.

Two examples of projects using siphon and electro-pneumatic drains to control slope stability are presented. The first example is a coast protection scheme constructed in 2004 at Castlehaven on the Isle of Wight in the United Kingdom. The second example involves landslide problems affecting remediation works to slopes undertaken in 2009 at a former open cast brown coal mine at the Most Ležáky site in the Czech Republic.

\section{Introduction}

One of the main triggers for landslides is groundwater. Drainage is therefore a proven measure for stabilising landslides. Many drainage systems are available to remove groundwater each with their own advantages and disadvantages.

Since 1986, French engineers have developed a novel technique for landslide stabilisation using one or more lines of vertical wells with gravity extraction of water, through continuously primed siphon tubing, for use where soil permeability and consequently abstraction flows are low; a technique named siphon drains ${ }^{\odot}$ (Gress, 1996). Today about 200 siphon drain sites have been installed to stabilise shallow landslide areas in France, United Kingdom, Switzerland, Italy, Romania, Slovakia and the Czech Republic.

Each well is pumped individually through siphon tubing where the tubing diameter is adjusted to the required flow rate. Each siphon tube is regulated by a hydraulic accumulator equipped with an internal siphon inducing a flushing effect, needing no power and with no moving parts. However, their operation in vertical wells and capability to drawdown the water surface is limited to approximately $9 \mathrm{~m}$ from the top of each siphon tube, since this is the theoretical maximum height of water that can be lifted by a siphon. 
Where pumping of groundwater is required to greater depths an alternative system has been developed using electro-pneumatic pumps. These pumps expel water from the wells using a compressed air system.

\section{Siphon and electro-pneumatic drains principle}

\subsection{Siphon drain principle}

The system comprises lines of vertical drilled wells installed within the landslide body. These wells are generally spaced at between 3 to $6 \mathrm{~m}$ and must be sufficiently deep to reach the layers to be drained. The wells are passively pumped using small diameter siphon tubes in a casing that permanently holds water and is placed in to the bottom of the well. Downslope of the line of wells the outflow end of the siphon tubing is placed in a manhole(s) at the same elevation as the bottom of the tubing in the upslope line of wells (upslope) section of the siphon line. The downstream end of the tubing is connected to an automatic flushing system which maintains the siphon within the water filled tubing. The elevation control (horizontal plane of reference) is important to maintain a siphon to develop in the tubing. The diameter of the tubing (generally 10 to $30 \mathrm{~mm}$ ) controls the theoretical volume of water flow from each well.

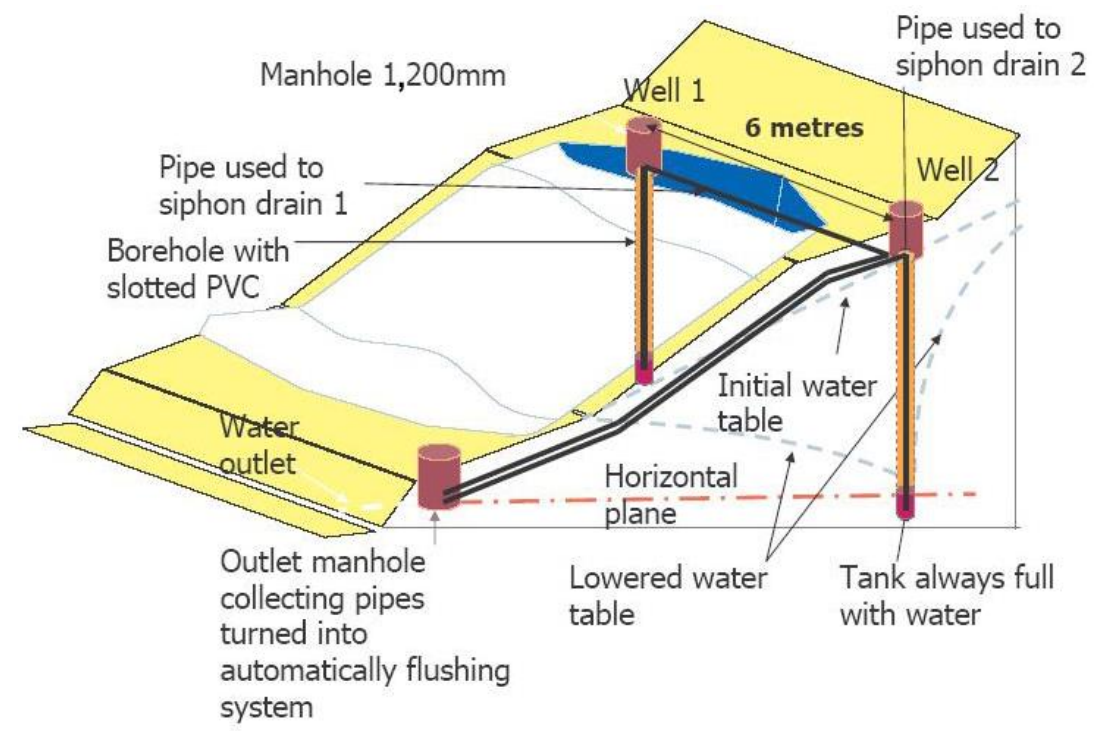

Figure 1 Cross section of a siphon drain network

Water is continuously maintained within the siphon tubing. When the water level rises in the well to a sufficient height above the bottom of the end of the siphon tubing, water will start to flow through the tubing due to the siphonic effect towards the downstream end of the system. The flow will continue until water levels in the well falls back to the level of the bottom of the tubing in the well.

For the system to operate it is important that the flow rate in the siphon is sufficient to keep the siphon primed. As the water rises towards the top of the siphon the pressure falls, and may approach a perfect vacuum. In the upstream section the low pressure causes small bubbles of gasses dissolved in the water to appear. These bubbles tend to coalesce into larger ones further downstream. Buoyancy and hydraulic forces due to the flow in the tubing tend to act on the bubbles. If buoyancy is the major force, the bubbles will collect at the summit of the tubing and combine into a single large bubble, which in time would break the siphon flow. This is avoided by using a system that automatically flushes out bubbles by turbulent flow.

The flushing system consists of a PVC pipe arrangement at the downstream end of the siphon tubing which acts as a hydraulic accumulator. When the water level in the upstream end in the drainage well is nearly the same as the accumulator there is no flow in the siphon tubing. When the water rises in the well the siphon action begins and water rises within the accumulator chamber. The pressure within the inner accumulator chamber reaches a critical pressure at the top of the chamber and causes a sudden release by simple flushing of water out of the chamber through a non-return valve at the base. This sudden lowering 
of the level of water in the accumulator is the key to the operation of the siphon and causes flow in the siphon tubing which is sufficient to flush out any air bubble within the siphon. It is important that both the siphon tubing and pipework in the accumulator is correctly sized to achieve a sufficient flow rate to remove the air bubbles from the siphon tube and provide the required groundwater drawdown. Flow continues in the siphon until the water level in the well is lowered to the same level as in the accumulator. The water level will then again rise in both the well and accumulator flushing system up to the predetermined level and then the flushing cycle starts again. The siphon system is shown in Figure 2.

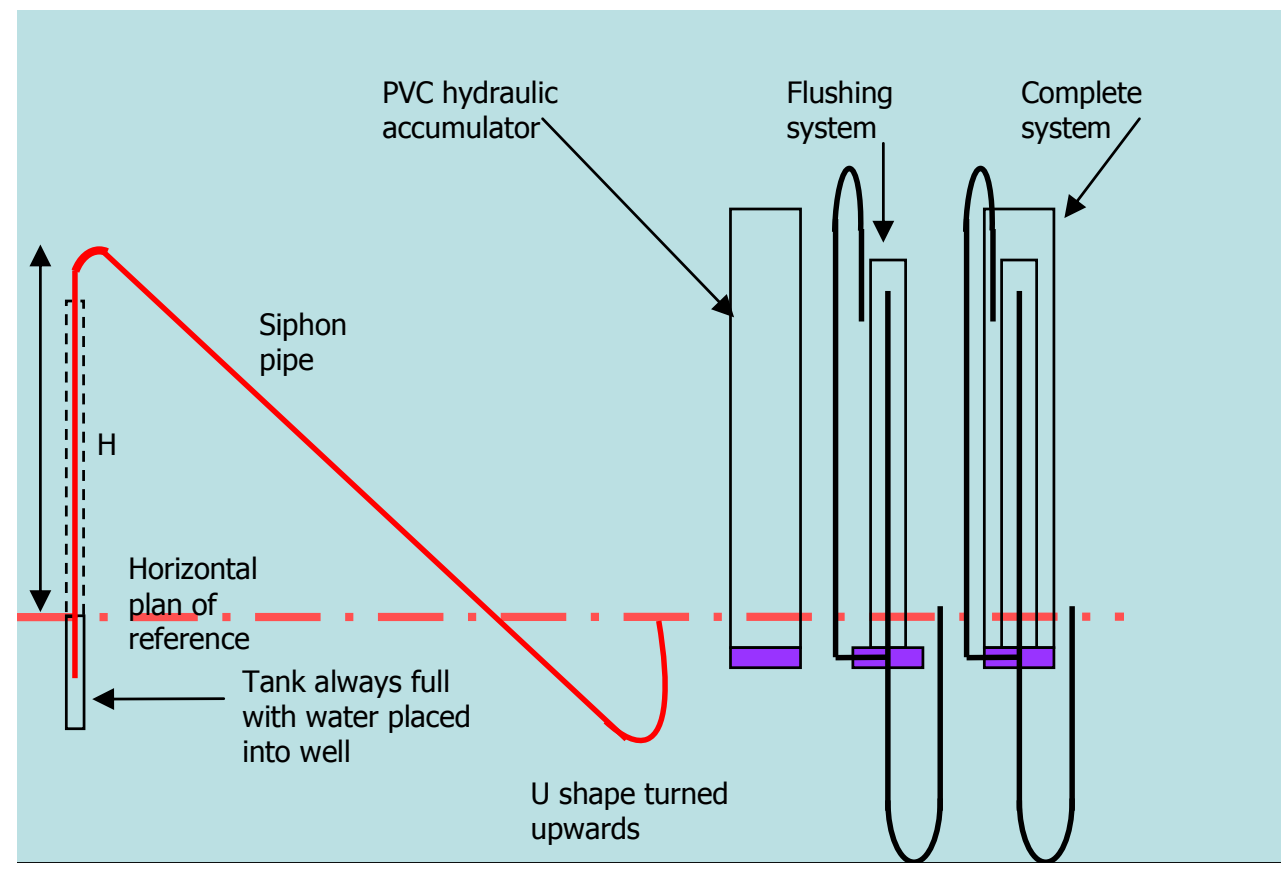

\section{Figure 2 Siphon principle - flushing siphon description}

The deep drainage system using siphon drains requires a network of wells, manholes and interconnecting ducts through which the siphon tubes run. The main components comprise:

- Well manholes, minimum $1.5 \mathrm{~m}$ depth (to prevent frost action) and 0.8 to $1.2 \mathrm{~m}$ diameter.

- The wells are typically around $200 \mathrm{~mm}$ diameter with $100 \mathrm{~mm}$ diameter slotted uPVC casing and fine gravel filter surround and installed through a pre-formed opening in the base of each manhole.

- Spacing between each well generally between 3-6 m.

- Typical maximum distances between siphon well and accumulator for well efficiency is $100 \mathrm{~m}$.

- A polyethylene duct up to $300 \mathrm{~mm}$ diameter between each manhole for siphon tubing.

- The duct is linked to an outlet manhole, downhill of the siphon well location, into which the hydraulic accumulator is installed, one per well.

- Downstream of the outlet manhole, the water is discharged to a suitable outfall.

- The siphon tubing varies from 10 to $20 \mathrm{~mm}$ diameter allowing for flows of between 2.9 to $24 \mathrm{~m}^{3} /$ day respectively.

\subsection{Electro-pneumatic drain principle}

The electro-pneumatic pump is similar to an electrical submersible pump but with no moving parts. It is simple in design and operation and uses an external compressed air supply that expels water out of the well. 
The electro-pneumatic drainage system adopts a similar arrangement to that for siphon drains and includes the pump, a network of manholes and ducting for electrical cabling and piping for water discharge at each manhole and also requires a compressed air supply, air storage tanks, dryers and filters and a control panel to operate the electro-pneumatic pumps.

The electro-pneumatic pump is installed in each well at the required drawdown depth. The control panel contains a relay and solenoid that controls the operation of the compressed air supply to each pump. The solenoid switch controls the compressed air supply allowing it to pass from the air compressor and its air tank to the compressed air inlet tube to the pump. The air is cleaned and dried by an air dryer and filters prior to entering the solenoid. An electrical cable, which is connected to the water level detector in the pump, is linked through the duct to the control panel.

When the groundwater rises in the well, it fills the pump chamber through a non-return ball valve at its base. The pump operation is controlled by two electrical sensors in the pump chamber. These two sensors are linked to the relay, which opens the solenoid. Compressed air passes through the inlet air tube to the top of the pump chamber, filling it with air and pushing water out of the pump through the outlet tube to the ground surface to discharge into the manhole. A non-return ball valve prevents any pumped water coming back in the pumping chamber.

Air compressors, air storage tanks and a control panel are typically housed within a small control building usually located within the area of the drainage network. Robust and reliable control systems (SCADA) are designed to remotely monitor the operation of the control panel and the performance of the pump operation and well drawdown efficiency.

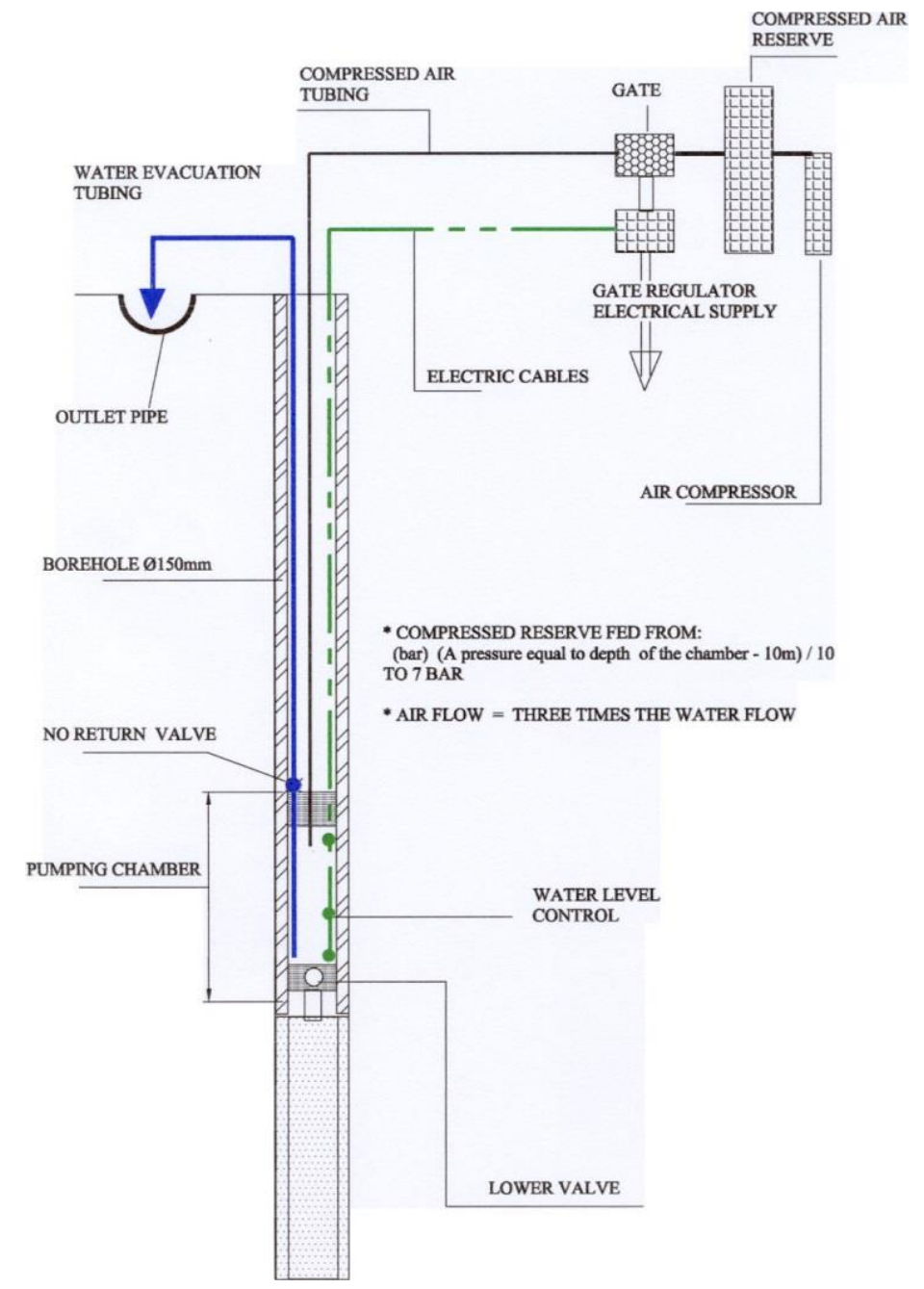

Figure 3 Electro-pneumatic pump system 


\section{Castlehaven coast protection and landslide stabilisation scheme}

Castlehaven is located on the southern most point of the Isle of Wight (IOW), in the United Kingdom (UK) just south of the village of Niton and is the site of a coast protection and landslide stabilisation scheme. The scheme was completed in 2004 and was awarded the 2005 Fleming Award of the British Geotechnical Association. This part of the paper outlines details of the scheme and the water drainage solutions adopted to successfully stabilise the landslide.

Castlehaven is a fishing hamlet on the western side of Reeth Bay which is approximately $650 \mathrm{~m}$ in width. Reeth Bay is backed by actively eroding steep cliffs up to $15 \mathrm{~m}$ high and unstable coastal slopes above. The site forms part of a much larger undercliff which covers the southern coastal fringe of the IOW which is a post glacial landslide complex some $12 \mathrm{~km}$ in length and extends inland by $500 \mathrm{~m}$.

The exceptionally wet winters of 1994 and 2000/2001 resulted in landslide problems along many coastal areas of the IOW. At Castlehaven coastal erosion, high groundwater levels and susceptible geology have contributed to the reactivation of this landslide where an estimated GBP 18 million of assets were at risk in an area of significant environmental importance.

\subsection{Ground model}

The strata consist of an interbedded sequence of Cretaceous rocks including the Upper Greensand which forms the inland cliff of the landslide backscarp some $500 \mathrm{~m}$ from the coastal cliffs. This is underlain by the Gault clay, which is notorious locally for being susceptible to instability and is known as the 'Blue Slipper'. This in turn is underlain by the Carstone, the Sandrock and Ferruginous Sand of the Lower Greensand. The solid geology of the area dips south at approximately 2 degrees towards the sea.

The hydrogeology comprises essentially an interbedded sequence of relatively high and low permeability strata. The permeable Upper Greensand forms the main aquifer. Downward drainage of the groundwater is restricted by the underlying Gault clay aquiclude which forces drainage along the shallow dip towards the active landsliding at the coastal edge. The Lower Greensand Carstone, Sandrock and Ferruginous Sand form a confined aquifer.

The in situ strata of the Upper Greensand escarpment are obscured by landslide debris and groundwater feeds into and infiltrates the landslide complex debris. The landslide is further recharged by artificial drainage from uncontrolled surface soakaways, highway drainage and foul sewage from septic tanks from all the properties in the area. Local zones of high flow were also suspected along a fossil valley axis cutting through the escarpment and behind back tilted blocks.

Detailed geomorphologic mapping and borehole investigations confirmed that the landslides are divided into an upper tier or inland area of multi-rotational failures separated from a seaward or lower tier of compound landslides by exposure of a Gault clay scarp. The extent of the upper tier landslides was determined from the degree of disturbance of the Gault clay within the exploratory boreholes which separated the slipped 'Gault clay Debris' from the intact Gault and from inclinometer data (Clark et al., 2007).

The landslide debris in the upper tier varied in thickness across the site increasing inland and consisted of an upper zone of Upper Greensand debris up to $10.5 \mathrm{~m}$ in thickness overlying a zone of Gault clay debris up to $25 \mathrm{~m}$ in thickness. The groundwater levels similarly varied throughout the site with maximum recorded winter levels of approximately $6 \mathrm{~m}$ and $1 \mathrm{~m}$ below ground level at the rear and the front of the upper tier respectively. 


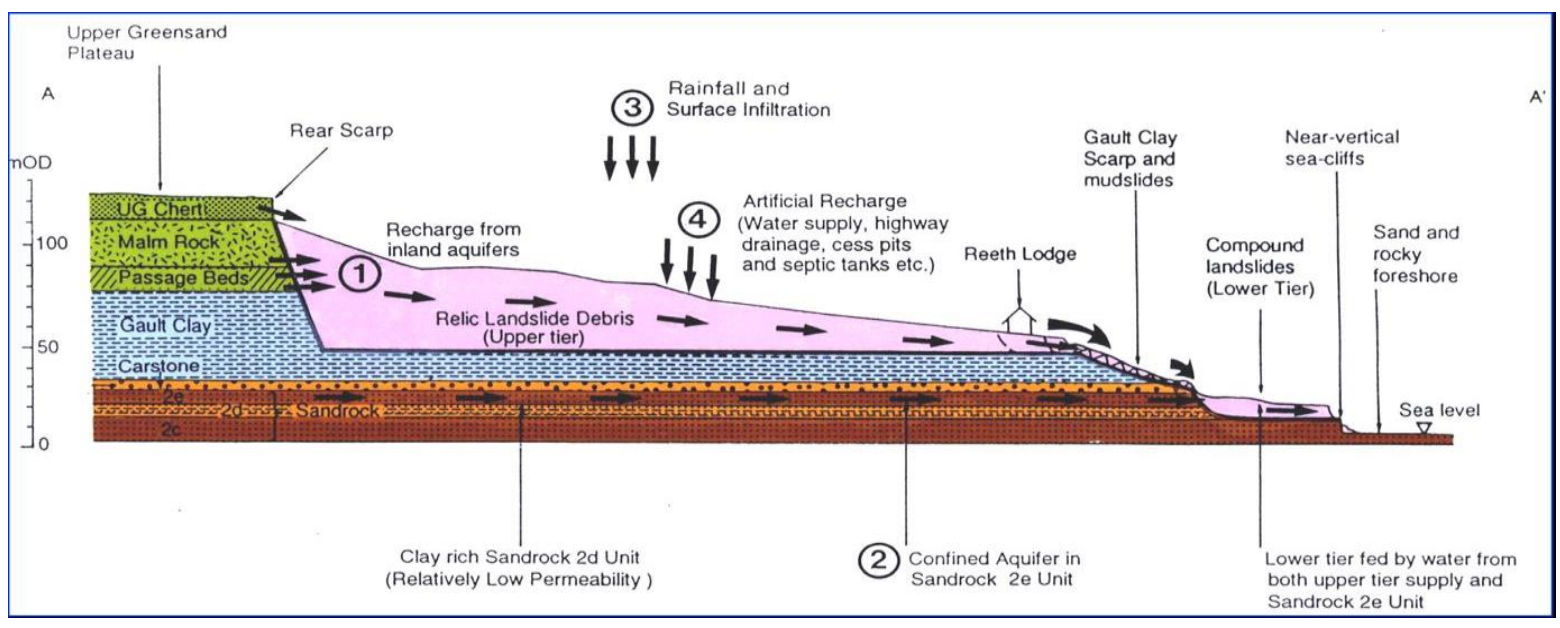

Figure 4 Generalised section showing geology and hydrogeology

Monitoring showed significant slope movement during the wet winters between 1994 and 2003. However, no significant movement was observed during the summer periods or dry winters. There are continuous rainfall records for the area since 1992. Analysis of this data shows a good correlation between the onset of minor movement and a four month antecedent effective (4AER) rainfall in excess of c. $380 \mathrm{~mm}$.

Groundwater levels have been monitored in standpipe piezometers since 1996 and in both standpipe and vibrating wire piezometers continuously since 2002. In December 2002 major movement was recorded by two inclinometers installed during the 2002 ground investigations and by surface movement and datum point monitoring when the 4AER exceeded c.380 $\mathrm{mm}$ which was the basis for the revised triggering groundwater level at the site.

\subsection{Scheme design}

To address the problem of landslides and to reduce the risk to public safety, property and infrastructure a coast protection and landslide stabilisation scheme was designed. However, the choice of the design and the implementation of the scheme was complicated by the fact that the area is highly designated and protected for the environmental quality of the area (Clark et al., 2002).

In view of the overall thickness of the landslide debris and the severe environmental constraints imposed on construction in the area, it was evident that improvement in the stability of the upper tier landslide could not be achieved by major construction and the installation of physical strengthening of the ground with techniques such as piles, deep counterforts, re-grading, etc. Accordingly the design was developed which consisted of two elements, firstly the prevention of the erosion by the sea and landward retreat of the Lower Greensand cliff by construction of a rock armour toe and apron and secondly improving the stability of the upper tier landslide by drainage techniques. This part of the paper concentrates on aspects of the slope stabilisation and selection of the drainage techniques.

A fundamental objective of the scheme was to improve the stability of the landslide by reducing ground movement; however, this had to be achieved without significant detriment to the local environmentally sensitive habitats. The main criterion for the improvement in the stability of the landslide was to lower and maintain groundwater locally within the upper tier of the landslide to a level comparable to that experienced during typical dry summer levels when no significant movement occurs. The remedial measures available therefore could not completely stabilise the landslide and the design approach was to achieve a target improvement on the current Factor of Safety based on a required minimum groundwater drawdown to achieve a minimum 'Factor of Improvement' in excess of 1.10.

An extensive series of instrumented in situ permeability and pumping tests confirmed the landslide was a complicated heterogeneous mass with anisotropic and varied behaviour and permeability. Test results confirmed that the required abstraction rates and groundwater lowering could be achieved. The range of 
permeability for the Upper Greensand and Gault clay landslide debris was between 1.29 to $2.95 \times 10^{-6} \mathrm{~m} / \mathrm{s}$ and $3.95 \times 10^{-6} \mathrm{~m} / \mathrm{s}$ to $9.65 \times 10^{-8} \mathrm{~m} / \mathrm{s}$ respectively. Water sampling and chemical testing was carried out to assess the risk associated with bio-fouling and encrustations.

Slope stability analyses indicated that the groundwater drawdown to achieve the required factor of improvement was between 11.4 and $7.7 \mathrm{~m}$ at the rear and front of the landslide respectively. The analyses were conducted on a number of cross sections for typical slope and basal shear geometries using laboratory determined residual shear values, worst case ground water conditions with an assumed existing Factor of Safety marginally above unity.

To achieve the required level of drawdown a series of lines of deep wells was considered the most appropriate approach and a number of pump options were considered including electrical submersible, electrical pneumatic, electro-pneumatic and gravity fed siphon wells. Based on the thickness of the landslide debris that had to be penetrated by the wells, the level of drawdown required and a cost-benefit analysis of the whole life costing of each option, a combination of deep electro-pneumatic and gravity fed siphon wells was adopted.

High-Point Rendel and TPGEO jointly carried out development of the detailed design.

\subsection{Scheme details}

Works for the coast protection and slope stability improvement scheme in Castlehaven commenced in September 2003 and was completed in October 2004. The drainage system comprised a total of 116 gravity fed siphon wells and 35 electro-pneumatic pumped wells installed to depths up to $25 \mathrm{mbgl}$. The wells were constructed by rotary drilling using water flush and drilled at $217 \mathrm{~mm}$ diameter to allow use of a slotted UPVC casing of $103 \mathrm{~mm}$ internal diameter. The annulus between bore and casing was filled with a fine graded gravel filter of 2 to $4 \mathrm{~mm}$ size.

The wells were arranged in three lines: line 1 comprised 35 electro-pneumatic pumps sited at the rear of the landslide where the required drawdown was greater than the capability of a siphon system. To power the electro-pneumatic pumps, a compressor station and control system was constructed within a nearby underground chamber to mitigate noise impact on the local community.

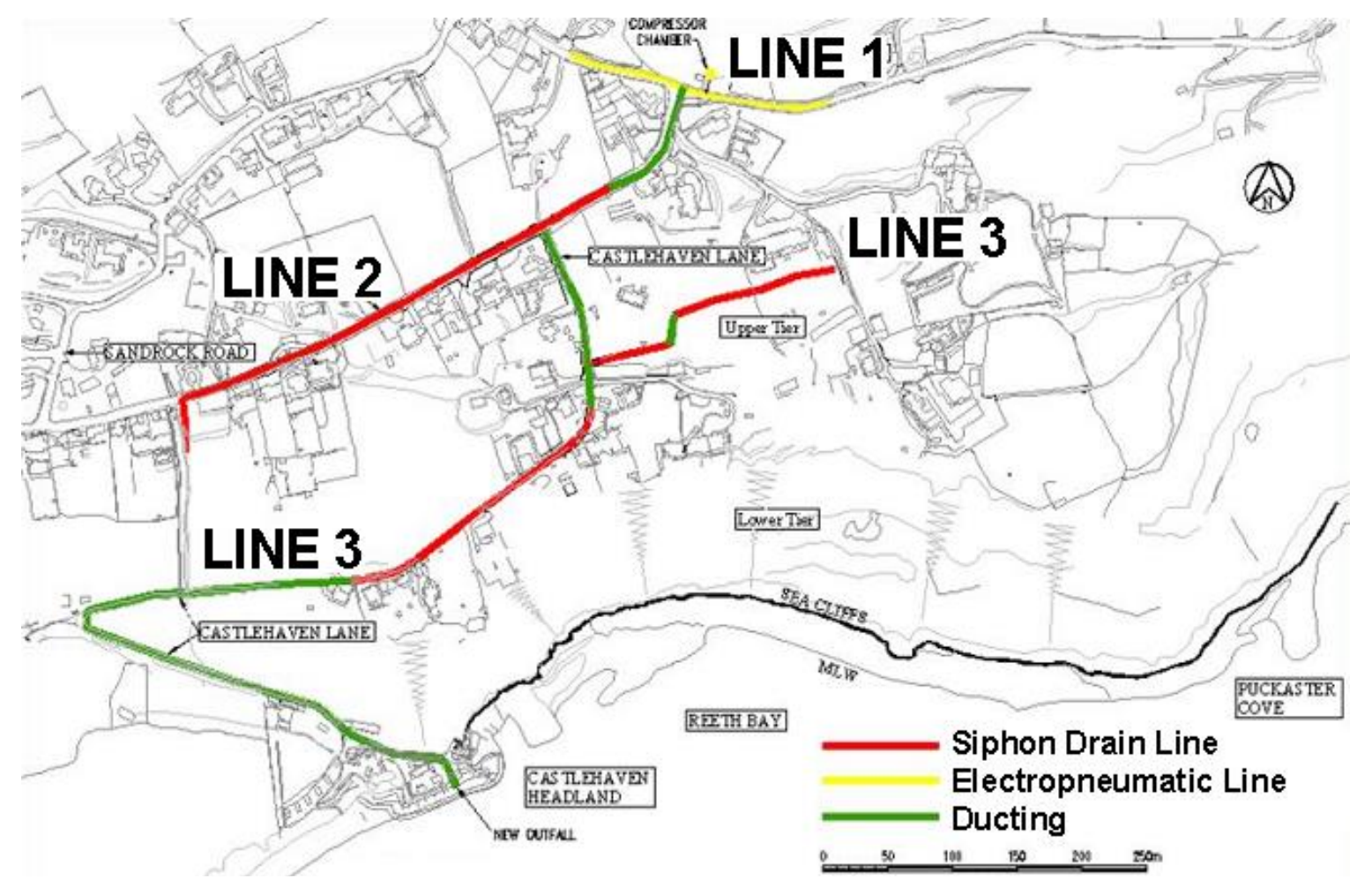

Figure 5 Castlehaven scheme drainage system layout 
The electro-pneumatic pumps were designed to draw down to a minimum of $15 \mathrm{mbgl}$. Line 2 comprised a total of 41 gravity fed siphon drains and line 3 comprised 75 siphon drains. Each siphon well (lines 2 and 3) was installed from the base of a manhole between 1.5 and $3.5 \mathrm{~m}$ deep which connected the trench drains and improved the theoretical drawdown to approximately $12 \mathrm{~m}$.

The drainage system included a total installed well depth of $3,180 \mathrm{~m}, 4,800 \mathrm{~m}$ of plastic duct pipe, 1,700 m of drainage trench, 206 manholes, 7,500 and 18,000 t of gravel trench backfill and spoil disposal respectively. Of a total construction cost for the project of GBP 4.5 million, the wells, siphons and underground compressor chamber were GBP 1.1 million and the drainage and infrastructure GBP 1.4 million (2004 prices).

\subsection{Scheme monitoring}

A comprehensive system of instrumentation and monitoring was established as part of the construction works. The purpose of the instrumentation and monitoring was to assess the effectiveness and performance of the slope drainage works against design assumptions and predictions and the performance specification and to verify long term performance of the scheme. Details of the instrumentation and monitoring are reported in a separate paper (Clark et al., 2007).

During the construction period the data from the instrumentation was reported initially two weekly reducing to monthly. Up to one year after construction the contractor and the specialist supplier (TPGEO) carried out two monthly performance reviews which compared the water levels in each well with the minimum drawdown levels (trigger Levels) given in the performance specification.

The performance review procedure included two water levels the 'alert' and 'action' levels at 1 and $2 \mathrm{~m}$ respectively above the specified Trigger Levels in each pumping well. If monitoring identified alert or action levels in any wells, then specified checking procedures, data interrogation and as necessary control measure responses were undertaken.

Of particular importance was regular maintenance which was scheduled every six months. Part of the maintenance procedures were to monitor for the possibility of siltation, iron or calcium carbonate encrustation or bio-fouling which could impede the long term performance of the wells. Flushing of the system during the regular maintenance is required to deal with siltation problems and additional purging with low concentration solutions of mild biodegradable organic acid are able to reduce bio-fouling.

\subsection{Scheme performance}

Following the commissioning of the drainage system there was an immediate response within the pumping wells and in the observation wells situated between the lines of pumping wells.

Observations at Castlehaven have confirmed the drawdown behaviour from the line of wells is generally in accordance with the procedures adopted for the scheme (Preene et al., 2000). This compares with the predictions prior to construction and demonstrates a good correlation in the results of predicted and achieved drawdown levels as a result of the drainage works in service. Drawdown profiles produced using these procedures are therefore considered appropriate for the ground conditions prevalent within the Undercliff landslide systems at Castlehaven. 
Typical results of the pumping and the drawdown of groundwater levels are shown in Figure 6.

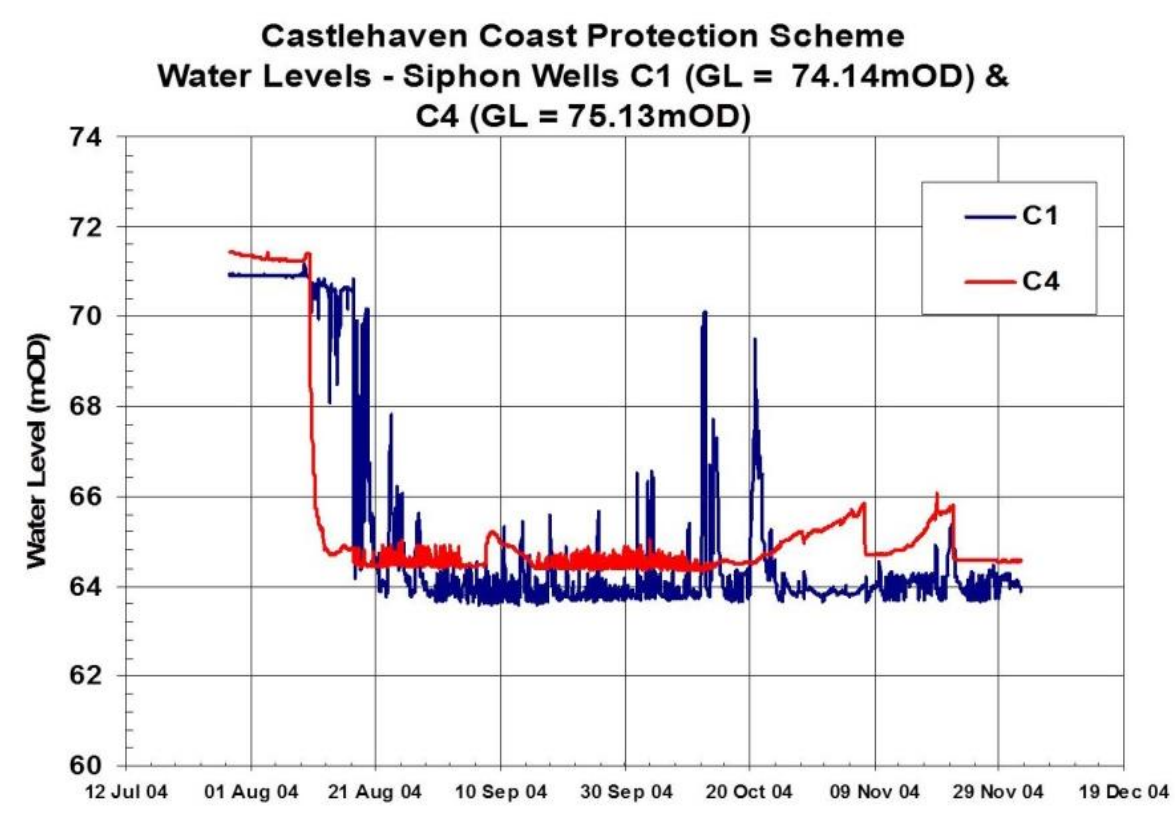

Figure 6 Monitoring and typical drawdown of some siphon drains

As expected, flow rates and rates of abstraction from individual siphon drains and electro-pneumatic pump wells were variable and reflected the anticipated variation in ground conditions and permeability. The variation in flow rates measured during installation and follow up visits from siphon drains and electro-pneumatic pump wells was generally in the range from 10 to $100 \mathrm{l} / \mathrm{hr}$ (i.e. 0.24 to $2.4 \mathrm{~m}^{3} /$ day) and 200 to $700 \mathrm{l} / \mathrm{hr}$ (i.e. 4 to $16.8 \mathrm{~m}^{3} /$ day) respectively. These flows are generally within the flow rates anticipated during the design of the scheme.

Water abstracted from the landslide was discharged to a sea outfall in Reeth Bay. Discharge rates have been monitored as part of the environment agency's conditions for discharge consent. The rate of discharge with time correlated well with the daily rainfall over the same period and confirmed a rapid response to rainfall. Monitored flows of up to $350 \mathrm{~m}^{3} /$ day have been recorded and do not exceed predicted long term base flow rates of approximately $441 \mathrm{~m}^{3} /$ day or maximum allowable rates of $500 \mathrm{~m}^{3} /$ day prescribed by the environment agency.

Following the maintenance period the scheme responsibility transferred to the local Coastal Protection Authority (Isle of Wight Council (IOWC)) and onsite training was given to IOWC staff on all aspects of the scheme. In addition a detailed procedure for scheme performance, monitoring and maintenance was prepared.

During the operation of the siphon drain pumps a rigorous maintenance protocol has been maintained to ensure their efficient operation. This requires both the removal of excessive build-up of silt within the tubing and also removal of iron oxidating bacteria sludge and encrustations in the well lines and hydraulic accumulators (Gillarduzzi, 2010). Currently three control visits are required per year to undertake flushing and cleaning of all the siphon tubing and hydraulic accumulators using specialist additives to control these problems.

It is important that the compressor system used to provide air to the electro-pneumatic pumps is effective and works efficiently. Power costs for the system were found to be relatively high (around GBP 15,000 per annum). 


\section{$4 \quad$ Most Ležáky open cast coal mine slope works, Czech Republic}

\subsection{Project description}

The Most Ležáky open cut coal mine site is located in the northern part of the Czech Republic between the towns of Most and Litvinov, in the central part of the Northern Bohemian brown coal basin. The mine is surrounded on its southeast, eastern and northern sides by embankments formed of clayey overburden as waste from the mine; by industrial zones and landfill on its northwest and west sides and by the main road corridor and Bilina River along the southwest sides and southern sides of the mine.

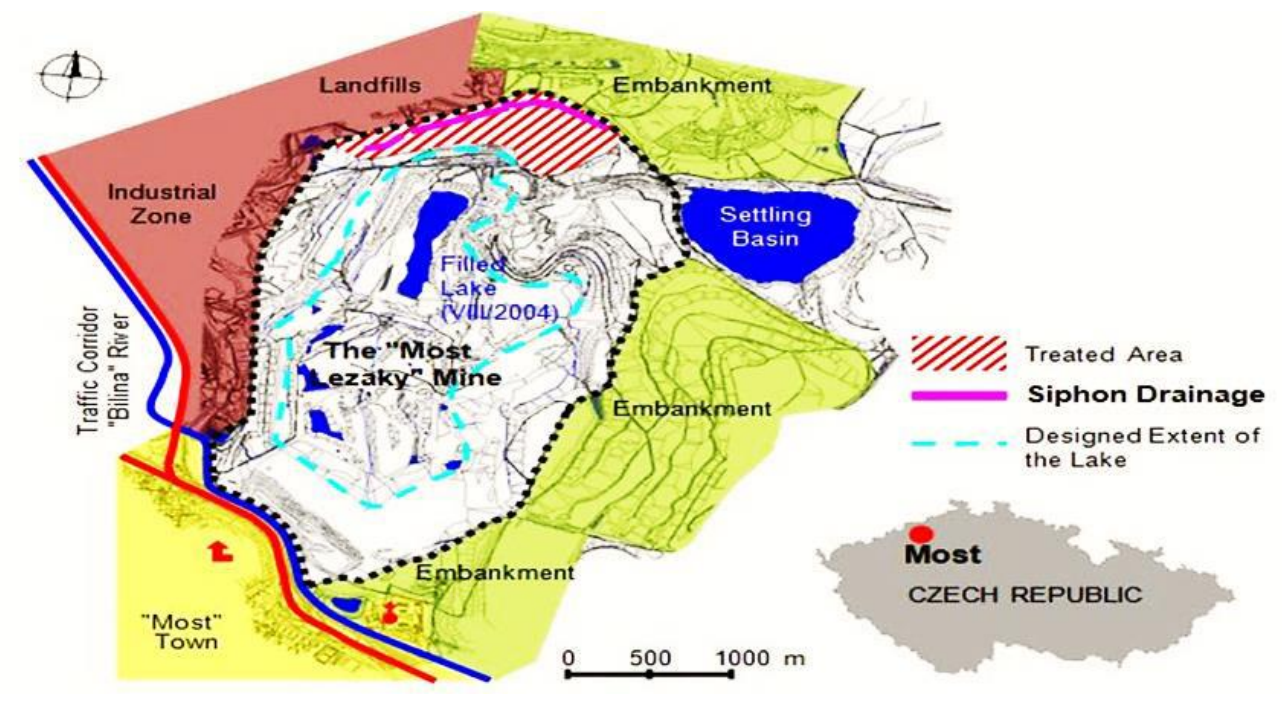

Figure 7 Most Ležáky site location and layout

Coal was extracted from the site in the 1970s and 1980s and the mine covered an area of approximately $2 \times 3 \mathrm{~km}$. By 1995 the rate of extraction was reduced and mining ceased in 2000. Since 2000, a programme to restore the mine has been in place. Part of the restoration plan is to form a lake (Lake Most) within the excavation. Filling of the excavation by infiltration and groundwater started in 2000 following mine abandonment. In 2008 additional water was pumped to the lake from a nearby dam. The final proposed level of the lake water is $199 \mathrm{~m}$ above sea level (masl) and was expected to be completed by 2011. Slope instability was noted within the upper sections of the northern slopes overlooking the mine during the mine restoration. Investigations and studies of slope failure types and mechanisms indicated rainfall and associated rising groundwater to be the main triggers to the landslide.

This part of the paper presents details of the project and describes the drainage measures adopted to stabilise the northern slopes using the gravity fed siphon drainage system.

The northern slopes were previously excavated to form cut slopes and wide benches. The slope varies in elevation from around 120 masl near the toe of the excavation to 270 masl at the crest. The geomorphology of the slope consists of (i) a relative level plateau behind the crest of the excavation slope, (ii) a series of benched and cut excavated slopes, and (iii) the mine floor.

The geology of the northern slopes comprises River Terrace Deposits (RTD) overlying a succession of clays and claystones and coal deposits. The RTD form the upper part of the northern slope and plateau and consist of silty sands and silty sandy gravels that vary in thickness between 0.2 to $6 \mathrm{~m}$. The RTD are a remnant of former fluvial processes that operated in this area during the Pleistocene. The main part of the excavated slopes is formed of highly weathered clays and claystone of Miocene age. The clays and claystones are highly weathered and disturbed to depths of up to $20 \mathrm{~m}$ below the interface with the RTD sands and gravels. The deep weathering and disturbance is thought to be due to deep freeze thaw action (cryoturbation) that operated during glaciations within the Pleistocene. 


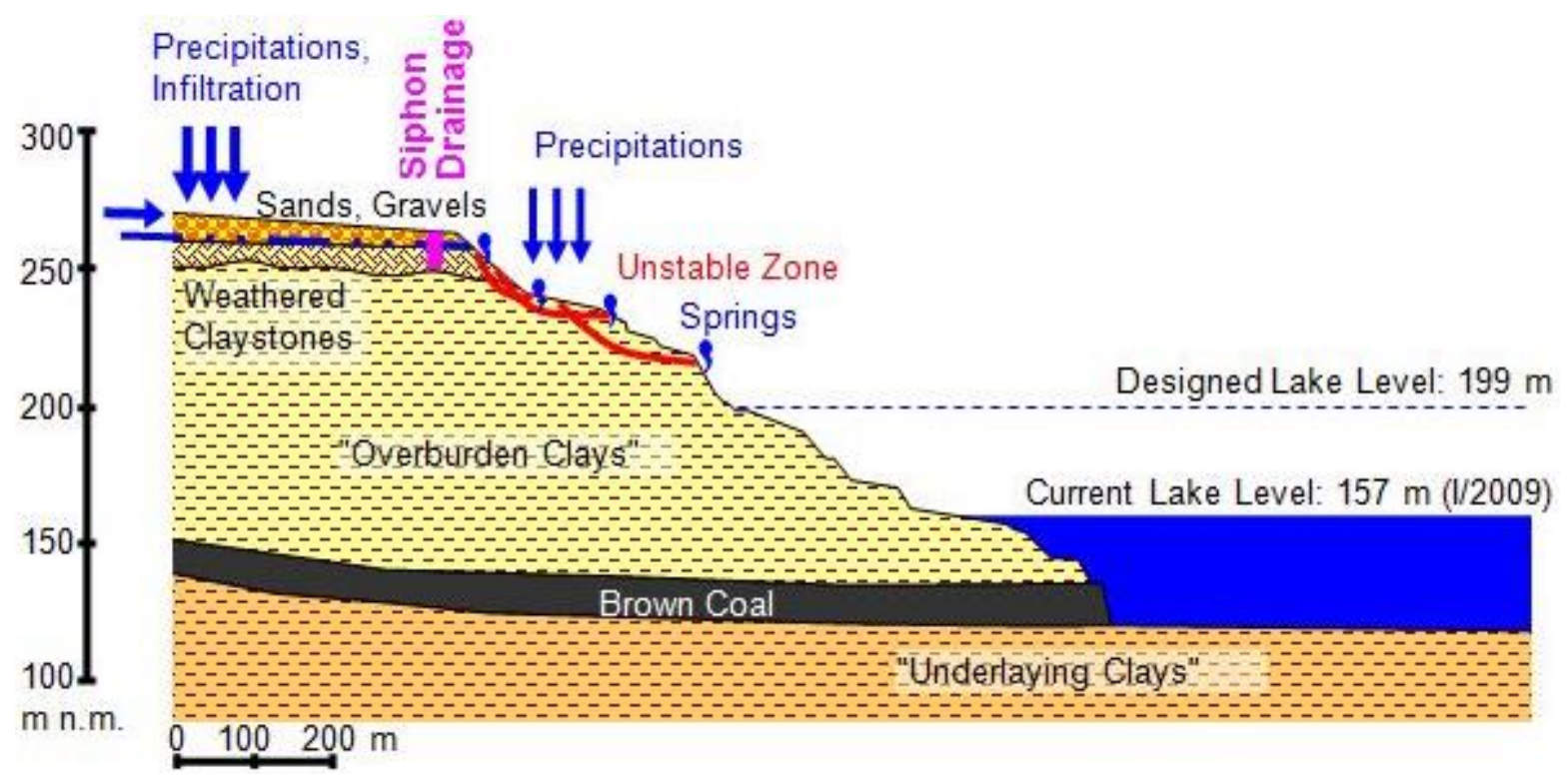

Figure 8 Cross section of northern slopes at Most Ležáky site

The northern slopes have been considerably modified during the mine operations and subsequent restoration. Some parts of the RTD were disturbed or removed during the mine operations and covered or mixed with overburden from the mine. Slope instability in the form of tension cracks and scars, back rotated blocks and both circular and planar type slope failures developed with time and affected a total length of slope of approximately $1,500 \mathrm{~m}$. The slope failures involved both the RTD and underlying weathered clay and disturbed claystone geology.

The site layout and hydrogeology has promoted the slope instability of the northern excavated slopes. The RTD plateau forms a large catchment to infiltration and the local dip at the interface between RTD and the underlying clays acts to direct groundwater flow south towards the excavation. Ground investigations within the area confirmed groundwater levels varying generally between 0.3 to $3.8 \mathrm{~m}$ below ground level and permeability of the terrace deposits ranging between $1 \times 10^{-4}$ and $1 \times 10^{-5} \mathrm{~m} / \mathrm{s}$. Groundwater flows from the RTD have saturated the underlying relatively permeable upper weathered and fissured zone of clay and claystone, leading to softening and reduction of strength with time and ultimately slope failure. The influence of groundwater on slope failure mechanisms was evidenced by the occurrence of typical surface water features including spring lines, ponds, and surface water flows within the slipped soil masses.

Saturation of the slopes by groundwater and by infiltrated surface water running out of the unconfined terrace deposits aquifer was assigned to be the main cause of instability. A project using gravity fed siphon drains was developed (i) to intercept groundwater flows in the RTD that fed the northern slope and (ii) to reduce the saturation and instability within the underlying clay and claystone strata.

\subsection{Project design}

The drainage system comprised a total of 255 gravity fed siphon drainage wells installed to depths of $11.5 \mathrm{mbgl}$ and with a spacing of $6 \mathrm{~m}$. The wells were constructed by rotary drilling using a water flush and the completed well was developed using air-lift. The well diameter enabled a slotted uPVC casing of $103 \mathrm{~mm}$ internal diameter to be installed centrally within the bore with the annulus between bore and casing filled with a fine graded gravel filter.

The wells were located within the upper benches of the mine excavation above the clay strata and arranged as three separate lines of wells that were orientated to follow slope contours. The locations were optimised to intercept flows into the excavation slopes and sited within stable areas that were assessed to be unaffected by previous slope instability. 
The lines of wells were connected by a system of conventional trench drains, ducts and prefabricated concrete ring manholes. Drainage trenches were taken to depths of 1 to $1.5 \mathrm{~m}$ and backfilled with gravel and a perforated drainage pipe to assist interception of groundwater. A $200 \mathrm{~mm}$ diameter duct was used to carry the siphon tubing from each well to the outlet manhole locations. The manholes at the top of each drainage well varied in elevation from $238 \mathrm{~m}$ to 265 masl but a minimum gradient of $2 \%$ was required between manholes to ensure gravity flow within the siphon tubing to the outlet manhole. The total length of the three separate lines of wells was 1,491 m.

A total of 23 outlet manholes were constructed on twelve separate drainage outlet lines to capture gravity fed flows from each of the local siphon drain wells. Each outlet manhole serves between 6 to 15 siphon well drains. The outlet manholes are equipped with the automatic flushing system (i.e. hydraulic accumulator). A $200 \mathrm{~mm}$ diameter duct was constructed from the outlet manhole and down the excavation slope to discharge the drainage water from the wells into the lake.

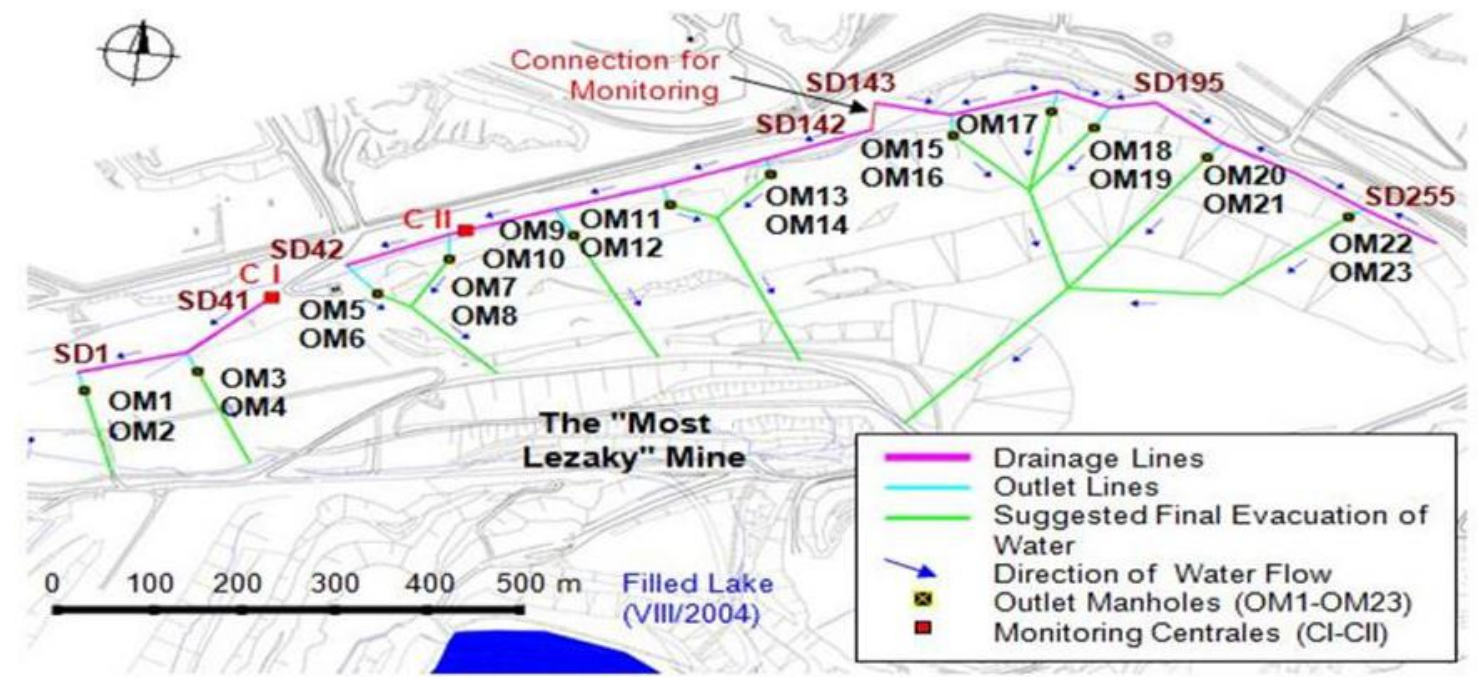

Figure 9 Siphon drainage system layout

Instrumentation is installed to monitor the drawdown performance and effective operation of the drainage wells. Groundwater levels are monitored (i) by a total of 50 vibrating wire piezometers installed to full depth within selected wells at regular intervals along the line of wells and (ii) by a series of dataloggers. The instrumentation was divided into five separate sections for ease of operation and control. Each section comprised a total of 10 vibrating wire piezometers connected by data cable (running through the duct system) to a 12 channel datalogger housed within one of the outlet manhole chambers.

An automated monitoring system has been installed. This system allows remote interrogation of the results of the instrumentation together with transmission of the data using a GSM modem. Groundwater levels are captured and processed by the contractor TPGEO. The client can access the processed data as simple charts provided on an internet interface on the web pages of TPGEO.

Regular maintenance of the siphon wells, tubing and flushing system is required throughout its design life to guarantee proper function and long term performance of the drainage system. Maintenance is in the form of regular control visits undertaken by TPGEO. The frequency of the control visits can be influenced by factors especially groundwater quality and chemistry but also groundwater flow conditions.

For this project the recommended duration of a control visit for the whole drainage system was estimated to be five days for two to three technicians. Control visits are required to be undertaken at least three times per year. A control visit typically includes general site inspections; measurement of groundwater inflow and siphon tube flows; flushing and cleaning of all siphon tubes and hydraulic accumulators; increase in number and/or change of siphon tube diameters (in case of significant change in water flows into wells). A report on each control visit is prepared including all inspection records and any corrective measures that may be required. Individual siphon drain sheets are recorded with each control visit. 


\subsection{Project performance}

The slope stabilisation works were completed in 2009 and the drainage system has enabled the control of groundwater to design levels and prevent further slope instability.

The anticipated ground and groundwater conditions were confirmed during the excavations of the trenches for the siphon wells and the outlet manholes. Preliminary values of water inflow into wells of 0.5 to $4.0 \mathrm{l} / \mathrm{min}\left(0.72\right.$ to $5.70 \mathrm{~m}^{3} /$ day) derived from the air lift pumping were verified by maximum flows recorded per siphon well of between 0.86 to $6 \mathrm{~m}^{3} /$ day.

The flow from the wells was not always constant. Some wells flowed continuously during the maintenance period. Some wells recorded variations in drawdowns due to the flushing system efficiencies. Groundwater level variations were found to match the rainfall records for the area. In all cases, the monitored flow rates were as anticipated in the design. The areas of permanent water flow from wells coincided to areas that had been most affected by instability and landslide in the past.

\section{Conclusions}

Innovative deep drainage methods using gravity fed siphons and electro-pneumatic pumped wells have been used successfully in many sites in the UK and Europe and are applicable to a wide range of slope stability problems where high groundwater levels trigger major slope failures.

The siphon system is simple to operate and has relatively low capital and operational costs since the siphon does not require any source of power to operate. It is extremely flexible and can be modified to respond to changing conditions. For example, if required, the system can be retrofitted with additional tubing to increase the discharge output of the system to allow for increased inflow due to higher future predicted rainfall intensities.

The electro-pneumatic pump system has also proved to be an effective method of pumping water from wells, however, the system relies on the associated compressed air and control systems required for them to operate efficiently and cost effectively.

It is very important to recognise that gravity fed siphons and electro-pneumatic pumped drainage systems require regular maintenance and cleaning to ensure their efficient long term operation. Maintenance is typically required two to three times a year. Instrumentation and monitoring can enable real time control on the function and efficiency of the drainage system.

A thorough assessment of groundwater chemistry and bacterial composition is recommended to minimise risk of potential development of encrustations and/or bio-fouling impacting on the long term operation and performance of the drainage system.

\section{Acknowledgement}

The authors gratefully acknowledge the cooperation and assistance throughout the two projects as follows:

Castlehaven coast protection and slope stabilisation scheme:

- Client: the IOWC.

- Principal contractor: Van Oord UK Ltd including T J Brent Ltd and TPGEO of France.

- Tony Bracegirdle as geotechnical advisor to High-Point Rendel.

- The many colleagues at High-Point Rendel particularly the construction supervision team of David Hattersley, Dan Squires and Peter Grice.

Most Ležáky open cast coal mine - slope stabilisation works:

- Client and principal contractor of earthworks and drilling: AZ SANACE, a.s. Czech Republic.

- Designer of slope remediation works: AZ Consult, spol. s r.o., Czech Republic. 
- General executor of the slope remediation works: Šilhánek a Syn, a.s., Czech Republic.

- Project sponsor: Palivový kombinát Ústí, s. p., Czech Republic.

- Sub-contractors for siphon well installations: TPGEO, France; Proexrom, Romania, and Stump FORATEC AG, Switzerland.

\section{References}

Bomont, S., Fort, D.S. and Holliday, J.K. (2005) Two applications for deep drainage using siphon and electro-pneumatic drains. Slope works for Castlehaven Coast Protection Scheme, Isle of Wight (UK) and slope stabilisation for the Railways Agency, France, in Proceedings International Conference on Landslide Risk Management and 18th Annual Vancouver Geotechnical Society Symposium, 31 May-4 June 2005, Vancouver, Canada.

Clark, A.R., Storm, C.V., Fort, D.S. and Mclnnes, R.G. (2002) The planning and development of a coast protection scheme in an environmentally sensitive area at Castlehaven, Isle of Wight, in Proceedings International Conference on Instability, Planning and Management, R. McInnes and J. Jakeways (eds), 20-23 May 2002, Isle of Wight, UK, Thomas Telford Publishing, Texas, pp. 509-518.

Clark, A.R., Fort, D.S., Holliday, J.K., Gillarduzzi, A. and Bomont, S. (2007) Allowing for climate change: an innovative solution to landslide stabilisation in an environmentally sensitive area on the Isle of Wight, in Proceedings International Conference on Landslides and Climate Change - Challenges and Solutions, R. McInnes, J. Jakeways, H. Fairbank and E. Mathie (eds), 21-24 May 2007, Isle of Wight, UK, Taylor \& Francis, pp. 443-451.

Gillarduzzi, A. (2010) A review of symptoms and consequences of iron oxidizing bacteria in ground engineering, in Proceedings 11 th IAEG Congress (Geologically Active), 5-10 September 2010, Auckland, New Zealand, A.L. Williams, G.M. Pinches, C.Y. Chin, T.J. McMorran and C.I. Massey (eds), Taylor \& Francis Group, Theme 2: Managing geological risk.

Gress, J.C. (1996) Dewatering a landslip through siphoning drain - Ten years of French experiences, in Proceedings 7th International Symposium on Landslides, K. Senneset (ed), 17-21 June 1996, Trondheim, Norway, Taylor \& Francis, Vol. 3, pp. 1705-1708.

Preene, M., Roberts, T.O.L., Powrie, W. and Dyer, M.R. (2000) Groundwater control - design and practice, CIRIA Report C515, London. 